Быстрова, Е.А. Уракова, Е.Н. Шарыгина // Карельский научный журнал. 2019. - Т. 8. - № 2(27) C.31-34

3. Курбатова А.Л., Рубцова Н.В., Калачев Е.Ю. Проблемы и перспективы профориентационной работы в современных условиях / А.Л. Курбатова, Н.В. Рубцова, Калачев Е.Ю. // Азимут научных исследований: педагогика и психология. 2019. - Т. 8. - № 4(29) [Электронный ресурc] URL: https://cyberleninka.ru/article/n/problemy-i-perspektivy-proforientatsionnoy-raboty-v-sovremennyhusloviyah/viewer (дата обращения:11.07.2021)

4. Маслевич Т.П., Сафронова Н.Б., Минаева Н.Л. Инновационные методы привлечения абитуриентов (на примере исследования факторов мотивации)/ Т.П. Маслевич, Н.Б. Сафронова, Н.Л. Минаева // Вестник ОРЕНБУРГСКОГО ГОСУДАРСТВЕННОГО УНИВЕРСИТЕТА. 2018. № 6 (218) - С.5260

5. Милославский В.Г., Алиева Н.Х., Соловьев С.М. [и др.]. Теория и практика профориентации в России: проблемы и перспективы / В.Г. Милославский, Н.Х. Алиева, С.М. Соловьев [и др.]. // Молодой ученый. — 2016. — № 7 (111). — С. 905-911. — [Электронный ресурс] URL: https://moluch.ru/archive/111/27219/ (дата обращения: 11.07.2021).

6. Молоткова Н.B., Мищенко Е.C. SWOT-анализ как основа разработки стратегии развития профориентационной работы образовательной организации в условиях конкурентной среды / Н.В. Молотккова, Е.С. Мищенко // Вестник Самарского государственного экономического университета. 2010. - № 3(65) - С. 52-56.

7. Разумова М.В. Профориентация в России: становление, проблемы и перспективы / М.В. Разумова // Профессиональное образование и общество. 2014. - № 3 (11) - С. 49-57

\title{
Мережко Е.Г. \\ Организация словообразовательных наблюдений на первичном этапе ознакомления со словообразованием в начальной школе
}

ФГБОУ ВО «СГУ им. Н.Г. Чернышевского»

(Россия, Саратов)

doi: $10.18411 / \mathrm{j}-08-2021-42$

\section{Аннотация}

В данной статье раскрывается актуальность первичных словообразовательных наблюдений на подготовительном этапе изучения состава слов и словообразования в начальных классах, анализируются материалы ряда учебников русского языка с точки зрения рассматриваемой проблемы, предлагаются методические рекомендации по содержанию словообразовательных наблюдений в начальной школе до изучения словообразовательных морфем.

Ключевые слова: элементарная словообразовательная теория, словообразовательные наблюдения, подготовительный этап, семантикословообразовательные связи.

\section{Abstract}

This article reveals the relevance of primary word-formation observations at the preparatory stage of studying the composition of words and word formation in primary classes, analyzes the materials of a number of textbooks of the Russian language from the point of view of the problem under consideration, offers methodological recommendations on the content of word-formation observations in primary school before studying word-formation morphemes.

Keywords: elementary word-formation theory, word-formation observations, preparatory stage, semantic-word-formation relations.

Изучение состава слова и словообразования является важной частью языкового образования младших школьников. Без освоения данного раздела невозможно полноценно сформировать грамматическую (и, в целом, языковую) компетенцию. Знание состава слова и словообразования способствует обогащению и уточнению 
словаря, точности употребления производной лексики в речи, а также более глубокому, осознанному усвоению лексико-грамматических групп слов, их специфических признаков, отличительных особенностей (например, особенности словообразования слов разных частей речи, словообразовательные морфемы, свойственные той или иной части речи).

Известно, что изучение состава слова и словообразования начинается с подготовительного этапа. Задачами данного этапа являются подготовка младших школьников к усвоению элементарной словообразовательной теории и морфемики (понятий корня и однокоренных слов, словообразовательных морфем и пр.), обогащение словаря учащихся необходимой производной лексикой (на основе которой в дальнейшем и организуются словообразовательные наблюдения).

Уже на подготовительном этапе возможны наблюдения за признаками родственных слов, особенностями образования слов в русском языке, словообразовательными моделями, различиями слов в словообразовательной паре, подготовка к элементарному словообразовательному анализу (определению исходного, производящего слова). Первичные словообразовательные наблюдения лучше всего проводить на материале производных слов с прозрачной мотивацией, когда производное слово можно объяснить через производящее.

Рассмотрим, какие первичные словообразовательные наблюдения, проводимые до введения словообразовательных понятий, представлены в современных учебниках русского языка для начальных классов.

Для анализа нами были выбраны учебники русского языка УМК «Школа России» (В.П. Канакина, В.Г. Горецкий) и УМК «Перспектива» (Л.Ф Климанова, Т.В. Бабушкина).

Анализ учебников показал, что большая часть подготовительных упражнений, предшествующих изучению словообразовательной теории, направлены на наблюдение за признаками родственных слов, подготавливают младших школьников к ознакомлению с корнем и однокоренными словами.

Например:

Прочитайте.

Лиска, лисонька, лиса!

Ты в каких живешь лесах?

Лисий хвост замел следы.

Где лисичка? Видел ты?

(Н. Бетенькова)

Спишите стихотворение. Найдите родственные слова. Обозначьте в них общую часть $[1$, с.60].

Прочитайте родственные слова. Что обозначает каждое из них?

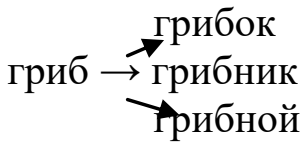

Что общего в лексическом значении этих слов? Найдите в родственных словах общую часть, в которой заключено это общее значение. Запишите слова. Выделите в них общую часть. От какого слова образовались слова грибок, грибник, грибной? [1, c.59]

Это упражнение организует наблюдения и за образованием слов.

Учебники, к сожалению, не содержат упражнения, предлагающие учащимся сопоставлять пары родственных слов (являющиеся словообразовательными парами) по значению и составу. Данные упражнения, в сущности, подготавливали бы школьников к выявлению семантико-словообразовательных связей между образованными друг от друга словами. Вместе с тем, есть упражнения, в которых учащимся необходимо 
сравнить слова одной словообразовательной модели. Например, перед введением понятия суффикса предлагается следующее упражнение (УМК «Перспектива»):

Прочитай слова. Кого они называют?

Лисенок, тигренок, котенок, мамонтенок, слоненок, страусенок, китенок, кенгуренок, олененок.

Найди общую часть в словах. Одинаково ли она пишется в разных словах? После какой части слова она стоит? [2, с.44]

Однако сопоставление предложенных в упражнении слов проводится достаточно формально и ограничивается лишь поиском общей части после корня (в сущности, выделяется один из признаков суффикса - его расположение относительно корня).

Встречаются и упражнения, организующие наблюдения за словообразованием слов, с использованием приема словообразовательного толкования значения производного слова, подготавливающие школьников к словообразовательному анализу. Но эти упражнения предлагаются уже в процессе изучения элементарной словообразовательной теории.

Следует, конечно, отметить, что такие упражнения эпизодичны, встречаются в данных учебниках крайне редко и не отличаются разнообразием.

С нашей точки зрения, на подготовительном этапе необходимо больше включать упражнений, направленных на выявление семантико-словообразовательных связей между производным и производящим словами. При этом данные упражнения должны учитывать этап обучения, проводиться на практической основе без опоры на словообразовательную теорию.

Поскольку младшие школьники еще до изучения состава слова уже знакомятся с понятием родственные слова, то в процессе специально организованных наблюдений можно дать представление и о ближайших родственных словах, т.е. парах слов, в которых одно образовано от другого, одно - первичное, другое - вторичное. Таким образом, мы можем уже на первом этапе через системные наблюдения и упражнения подготавливать школьников к осознанному словообразовательному анализу. Например:

1. Прочитайте.

В один из вечеров услыхал я за домом яростный лай собак. Пригляделся. Стоит маленький рыжий кабаненок. Прижался боком к стене, ощетинился, дрожит весь. Сходил я в дом, принес несколько картофелин. Сам спрятался. Рыжий съел, но не ушел. К людям кабаненок привык скоро. Назвал я его Рыжик. (А. Максимов)

О ком идет речь в тексте? Как автор назвал кабаненка? Почему? От какого слова образовано слово кабаненок?

2. Прочитайте. Найдите пару ближайших родственных слов. Какое из них первичное, а какое вторичное?

За город начал

Рыбак собираться.

Удочку взял,

Чтобы рыбу ловить.

Взял дождевик,

Чтобы им укрываться.

Взял самовар,

Чтобы чай кипятить.

(Э. Успенский)

Что означает выделенное слово? От какого слова оно было образовано?

3. Прочитайте пары слов. Какие из них являются ближайшими родственными словами?

Дом - домик, дождевой - дождливый, слон - слоненок, город - городок, береза березонька, чайник - чайка. 
В дальнейшем подобная подготовительная работа позволит облегчить младшим школьникам усвоение словообразовательной теории и преодолеть трудности морфемного анализа.

Таким образом, еще до изучения элементарной словообразовательной теории нужно проводить на практической основе достаточно разнообразные словообразовательные наблюдения и упражнения, а именно:

- подбор родственных слов с указанным значением;

- словообразовательное толкование производного слова;

- образование слов по образцу (по аналогии);

- подбор пар родственных слов (по аналогии, данному образцу);

- сравнение родственных слов по значению и составу (выделение общей части), в том числе и ближайших родственных слов (в словообразовательной паре);

- определение ближайших родственных слов в контексте или группе слов;

— замена выражения одним словом (образование слов с указанным значением);

— элементарный словообразовательный анализ, определение исходного, первичного (производящего) слова по отношению к данному и др.[3]

Итак, словообразовательные наблюдения необходимо начинать с первых этапов обучения. Это является важнейшим условием осознанного усвоения младшими школьниками элементарной словообразовательной теории в дальнейшем, формирования словообразовательных умений учащихся.

$$
* * *
$$

1. Канакина В.П., Горецкий В.Г. Русский язык. Учебник для 2 класса общеобразовательных организаций. В 2 ч.Ч.1./ В.П. Канакина, В.Г. Горецкий. - М.: Просвещение, 2017.143c.

2. Климанова Л.Ф. Русский язык: 2 класс: учебник для общеобразовательных учреждений с приложением на электронном носителе: в 2 ч. Ч.2. / Л.Ф. Климанова, Т.В.Бабушкина. - М.: Просвещение, 2013.143c.

3. Мережко Е.Г. Словообразовательные наблюдения в период обучения грамоте/ Проблемы филологического образования. Сборник научных трудов. Под редакцией Черемисиновой Л.И. Саратов: ИЦ «Наука», 2011. С. 26-29.

\section{Мизюрова Э.Ю. \\ Роль современных технологий в патриотическом воспитании студенческой молодежи}

Саратовский государственный аграрный университет имени Н.И. Вавилова

(Россия, Саратов)

doi: $10.18411 / \mathrm{j}-08-2021-43$

\section{Аннотация}

Патриотическое воспитание обучающихся является одним из ключевых направлений в воспитательной работе СГАУ имени Н.И. Вавилова. Анализируется роль иностранного языка как средства развития патриотических чувств у студенческой молодежи. Автор статьи указывает на высокий потенциал сквозных технологий цифровой экономики - виртуальной и дополненной реальности в целенаправленном, систематическом процессе воспитания всесторонне развитой, гармоничной личности с активной гражданской позицией.

Ключевые слова: патриотическое воспитание, студенческая молодежь, гуманитарные дисциплины, иностранный язык, цифровые технологии, творческие проекты. 